\title{
富栄養化水域における水質の短期的予測 \\ Short-term Prediction of Water Quality in Eutrophic Waters
}

\author{
大島省吾* ・藤田満士** ・ 中津川誠*** \\ By Shogo OHSHIMA, Mitsusi FUJITA and Makoto NAKATSUGAWA
}

\begin{abstract}
It is commonly thought that eutrophication seldom occurs in water areas, such as rivers and lakes, in snowy cold regions because of the climatic conditions. However, this does not apply to water areas where the nutrient load is high and where the streams have stagnated.

To cope with unusual phenomena in such water areas, such as water bloom, it is necessary to measure water temperatures and observe chlorophyll-a concentrations continuously to make short-term predictions a few day later.

In this report, we try to predict the water quality after a few days using online information about chlorophyll-a concentrations from hourly measurements of the water temperature and by using a fluorescence spectrophotometer. Also, the weather forecast of the week and the Kalman filter are applied to the ecosystem model of water quality.
\end{abstract}

As a result, we confirm that it is possible to predict changes in chlorophyll-a.

Keywords: Short-term prediction of water quality, Chlorophyll-a,

Ecological model, Kalman filter, Weather forecast for a week

\section{1. まえがき}

積雪寒冷地の河川や湖沼などの水域は, その気象条件等から富栄養化現象は起こりにくいと考えられ てきた.しかしながら, 水域周辺から流入する栄養塩負荷が多く, 水流の停滞する水域では, 富栄養化現 象のみられる個所もある. この様な水域の適切な水質管理には, 水質現象の連続的な観測 (監視), 水質現 象のメカニズムの解明と水質現象の予測 (予測), 水質現象の発生要因の軽減および水質浄化対策 (対策), の3点が重要と考えられる.

多くの水域で行われている水質の定期的観測は, 項目にもよるが一般に頻度が少ない. そこで, 水質変

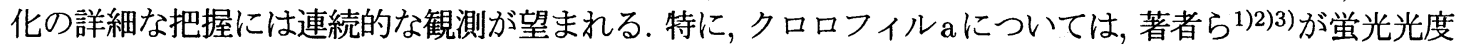
計による連続観測を実施してきており，この様な手法は富栄養化した水域の水質監視に有効と考える.

ところで，これまでの水質予測では数年先というような長期的視野で現象の推移をみて, それを計画論 や各種施策に活用しようとするものが主体であった. この場合, 流入量や気象といった各種境界条件の精 度から, 結果は実現象の予測というよりは, 感度分析的な結果として解釈されるものであった。

一方, アオコの異常発生のような水質上の弊害については, 管理者がそれをオンライン情報によって監 視し, 数日前にでもそれを予測できれば有効な対応を行うことが可能と考えられる. そこで, このような 実現象予測としての短期的な水質予測を連続観測データを用いたうえで行うことを試みた. この手法の 中では熱収支式や, 水質のモデリングで一般に用いられている生態系モデル4)により, 水温やクロロフィ ル $\mathrm{a}$ 濃度の推算を行った. また, 水温計や蛍光光度計から得られる毎時間の実測データから日平均值を求 め, カルマンフィルター5)を用いて計算結果を修正しつつ数日先までの予測をおこなった. この時, 境界 条件となる気温や日射量は週間天気予報をもとに与えた.

$\begin{array}{cllll}{ }^{*} \text { 正会員 } & \text { 北海道開発局開発土木研究所環境研究室 } & \text { 室 } & \text { 員 }(062 & \text { 札幌市豊平区平岸 1-3) } \\ { }^{* *} \text { 正会員 } & \text { 北海道開発局開発土木研究所環境研究室 } & \text { 副 室 } & \text { 長 }(062 & \text { 札幌市豊区平岸 1-3) } \\ { }^{* * *} \text { 正会員 } & \text { 工博 } & \text { 北海道開発局開発土木研究所環境研究室 } & \text { 主任研究員 }(062 & \text { 札幌市豊平区平岸 1-3) }\end{array}$




\section{2. モデル水域の概要}

本研究のモデル水域として, 石狩川水系千歳川流域にあるネシコシ排水池を設定した. 図-1にネシコ シ排水池の位置図を示す.ネシコシ排水池は, 平成元年までに段階的に掘削が進められ, 流下方向に約 $2,000 \mathrm{~m}$, 横断方向に約 $130 \mathrm{~m}$, 水深約 $1.5 \mathrm{~m}$, 勾配 $1 / 4500$ の形状となっている. 周辺の土地利用状況は畑地 が多く, 融雪による出水と灌溉期が一致する春期には栄養塩の流入が大きい. 気象概況は, 気温は夏期に $30^{\circ} \mathrm{C}$ 程度まで上昇し, 冬期には-20 ${ }^{\circ} \mathrm{C}$ 程度まで低下する. 降水量は年間 $1,000 \mathrm{~mm}$ を越え, $7 \sim 10$ 月に多い. 風速は, 年間を通して $5 \mathrm{~m} / \mathrm{s}$ 以上で, 夏期に南より冬期に北よりの風向が卓越している. 池内は, 水深に対 して流下方向の距離が大きく水流が風の影響を強く受けるため, 常時, 混合状態にある. さらに, 火山灰 やシルト質を主体とした細粒成分が流入したり巻き上げられたりして水の濁りが顕著である. 図-2にネ シコシ排水池の観測状況を示す.

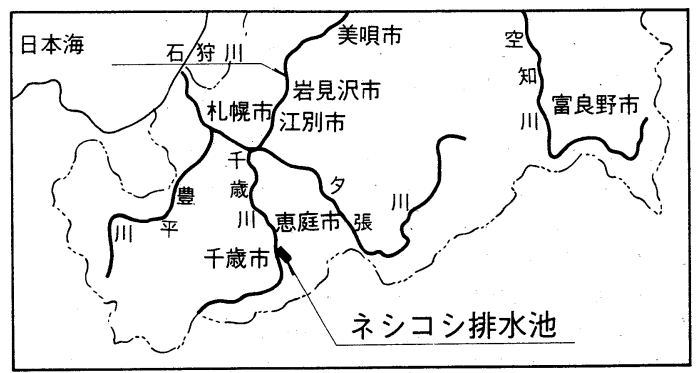

図-1＼cjkstart調査個所の位置

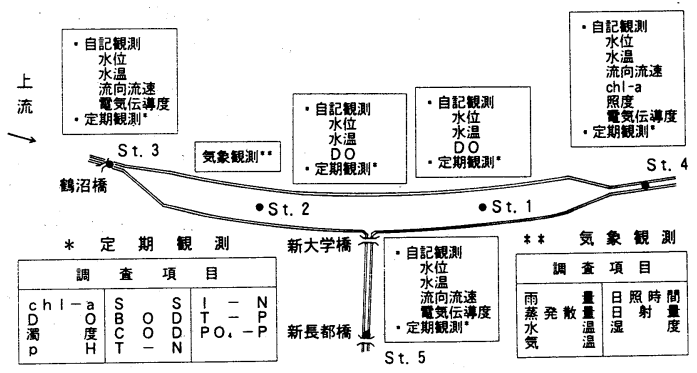

図-2 観測地点の位置と項目の内訳

\section{3. クロロフィルaの連続観測}

水域における水質監視には様々な方法がある が, 本研究では富栄養化水域における植物プラン クトンの変化の監視を中心におこなうことから， 蛍光光度計を用いてクロロフィル $\mathrm{a}$ の連続観測を おこなった.ここでの観測值は, 蛍光光度をクロ ロフィルaに換算することで得られるもので, 定 期的に室内分析の結果でキャリブレートするこ とにより,植物プランクトンの日周変動を含めた 詳細な変化を検出することができる.ただし，こ のままではクロロフィルの初期分解生成物であ るフェオフィチンを含んだ值であるため, 定期的 にフェオフィチンを測定し, その影響を取り除く ことによって精度の高い観測值を得ることが可 能となった. 図-3に 1994 年に蛍光光度計で得ら れたクロロフィル $\mathrm{a}$ を室内分析の結果と比較して

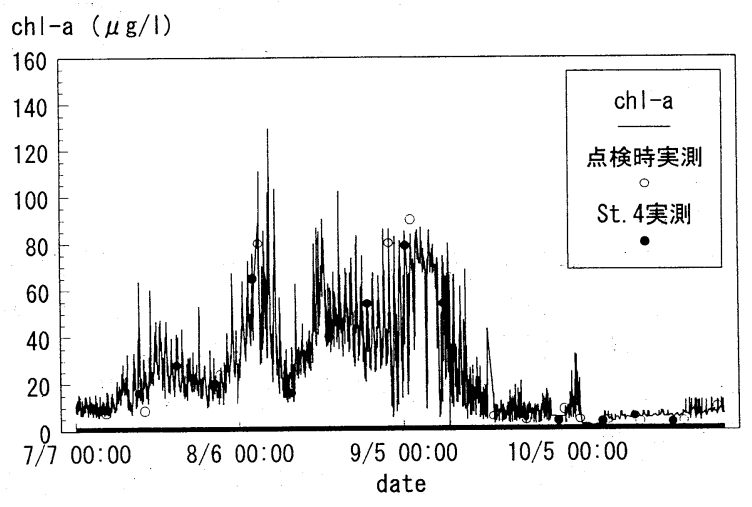

図-3 蛍光光度計による観測結果 (ネシコシ 1994 年) 示す.

\section{4. 水質のモデリングとパラメータの決定}

モデル水域における水質現象のモデリングと, モデルパラメータの決定を各種調査試験結果から行っ $た^{6) 7)}$.

\section{1 水収支の把握}

モデル水域は, 大きく 2 つ流入水路と 1 つ流出水路で 1 つ系をなしている. このような水域の水 質管理には, まず, 水収支の的確な把握が重要と考えられる. そこで, 各流出入水路に自記水位計ととも に自記電磁流速計を併設し, それをもとに流量を推定した. この時, 自記電磁流速計のセンサーは, 流量 観測時のデータをもとに断面平均流速と最も相関の高い位置を選んで設置している.また, 事前の測量に より水位一容量 $(H-V)$ 関係を求め, 自記水位計を池内 2 地点に設置し, 計測された水位から貯留量を推算 している. 図-4には, 流出入から推定した貯留量と水位-容量関係から推定した貯留量を比較しているが, これから十分な精度で池内の水収支が把握できていることがわかる. 


\section{2 熱収支の把握}

池内の水温変化を把握 するため, 池内の 2 力所に 自記水温計を設置し, 連 続測定を行った. 水温計の センサーは, 鉛直方向の 温度分布を測定するため に, 河床から $0.2 \mathrm{~m}$ の位置 之, 水面加 $0.2 \mathrm{~m}$ の位置 で水位変動に対応するよ うにして移動するように 設置した.この結果, 鉛直

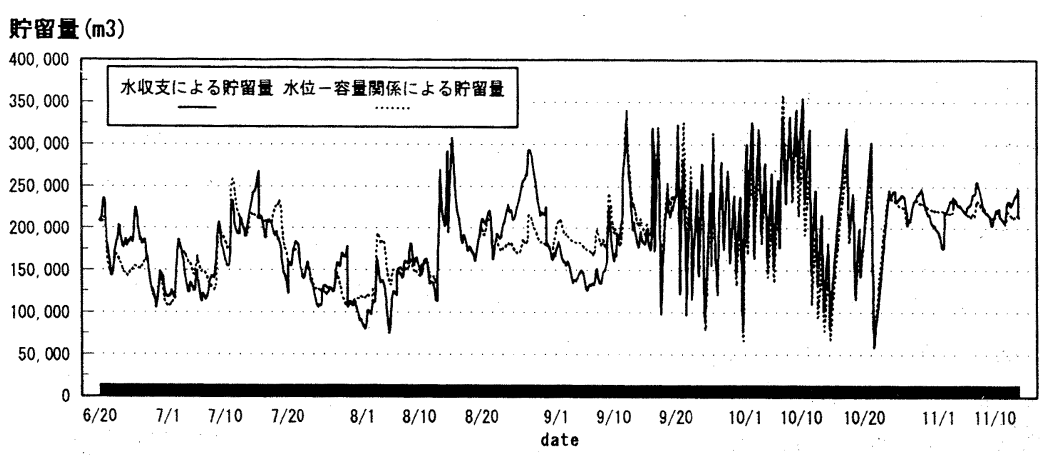

図-4 水収支の観測結果 (ネシコシ 1994 年)

方向については水温差はみられず, 水平方向には調查地点間 (St.1 と St.2) で $1 \sim 3{ }^{\circ} \mathrm{C}$ 水温差が確認され た.この結果よりモデルの構造を鉛直方向には 1 層, 水平方向には 3 ボックスに分割した $($ 各ボックス $671 \mathrm{~m}$ $\times 130 \mathrm{~m})$ 完全混合槽列モデルに決定した.

\section{3 水質成分の生成・消滅量の把握}

池内の水質変化は図2 に示すように定期観測 とともに自記観測をおこ ない把握した. それとと もに, 池内の水質成分の 生成・消滅量を (1) 藻類増 殖 (AGP) 試験や (2) 呼吸 による藻類消滅試験, (3) 光合成による DO生産量 試験, (4)COD物質による DO 消費率試験，(5) 底泥 物質によるDO 消費率試 験，(6) 有機物分解試験, (7) 底泥溶出試験, (8) 沈 降物試験といった試験を おこない，それらの結果 からモデルパラメータを 決定している.

このように得られた結 果を総合化してモデル化 し，水質現象の再現をお こなった.ここで用いたモ デルの基礎式を表-1に示 す.ここでは式(1)をみた すように水収支(貯留量, 流出入量, 降雨量, 蒸発 量)を明らかにし，式(2)， 式(3) を数值的に解くこ とで, それぞれ水温, 水質 の変化を再現した. 式(3) の中の変化項 $\mathrm{S}(\mathrm{C})$ は植物 プランクトンの増殖, 死 滅, 各水質成分の生産・分

\section{表-1 水収支 - 熱収支 - 水質成分収支の基礎式}

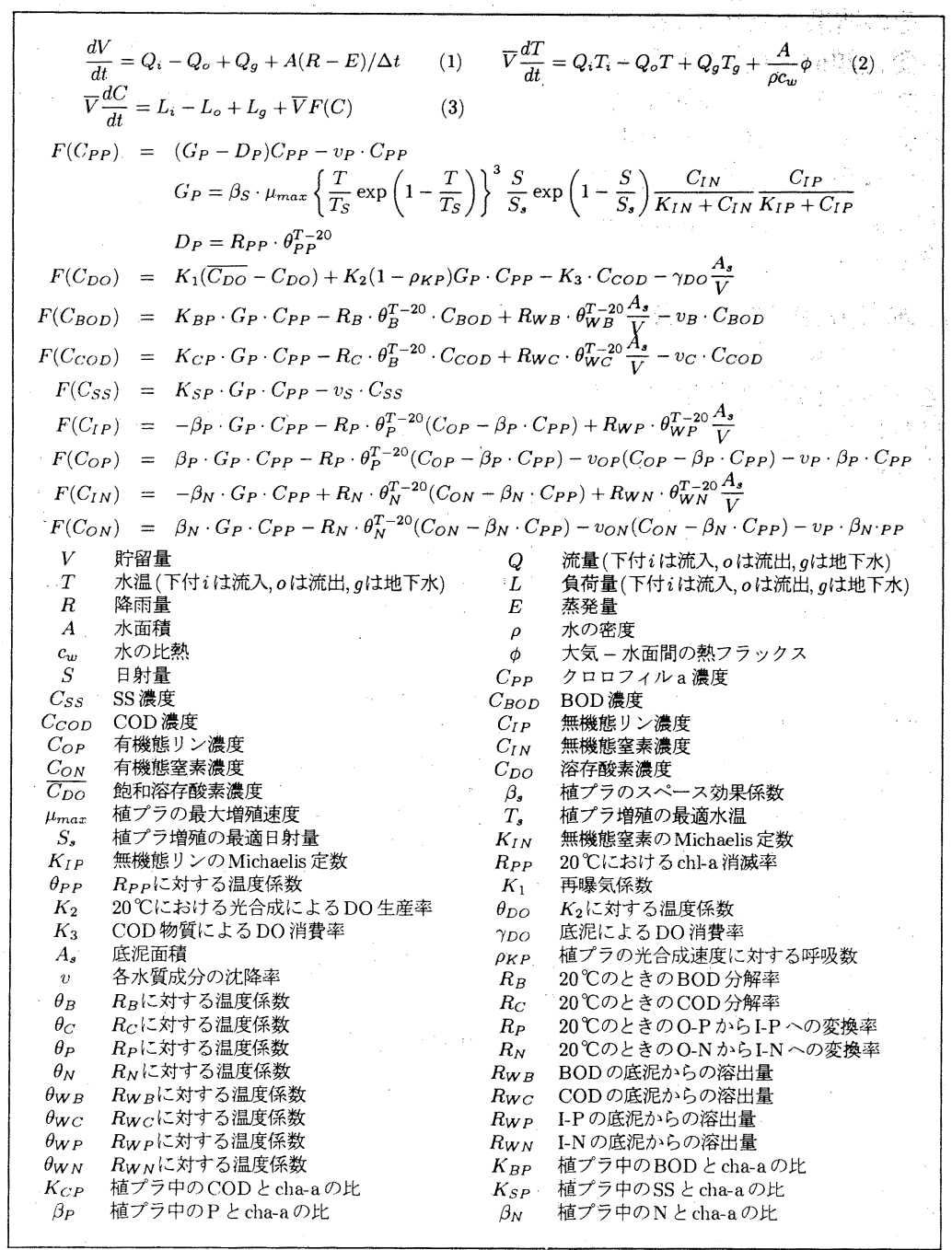


解, 底泥からの溶出, 底泥 への沈降を考慮した，いわ ゆる生態系モデルを用いて 定式化している. 計算対象 とした水質項目は，クロロ フィル $\mathrm{a}(\mathrm{chl}-\mathrm{a}), \mathrm{DO}, \mathrm{BOD}$, COD, I-P, O-P, I-N, O-N, SS の 9 項目である. 与えるデ 一タは, 気象データとして気 温, 湿度, 日射量(日照時間), 風速, 降雨量の5項目を, 水 文データとして, 流出入量, 貯留量を，さらに流出入に ともなう水温を与えている. また，水質成分の流入負荷 量は定期調査の結果をもと に, 負荷量-流量 $(L-Q)$ 関係 式から与えている.

その結果, 計算值は観測值 の変化傾向を的確に再現で きたことから，今回採用した モデルやパラメータが現地 の水質現象を捉えるうえで 十分妥当な值であることが 検証された 8 )。

\section{5. 水質の週間予測手法}

水質現象の再現性を踏ま え, その短期的予測手法の検 討をおこなった.ここでは日 平均值に対する再現予測を おこなう。図-5に予測の手 順を示す。

\section{1 予測手法}

予測にあたっては表-1の 式(2)が水温, 式(3)がクロ ロフィルaに関しての基礎方 程式となる. 水温予測につい ては, 既に報告9)してあるの で以下にクロロフィルaの予 測手法を示す.

まず，ボックス $k$ におりる

クロロフィルa の濃度に関する方程式を表-2の式(4), (5)のようにあらわす.これを式(6)のように一般 化し, ボックス構造を考えて, 式(7)のようにマトリックス表示する. これは線形式として扱えるので容易 に線形カルマンフィルターの適用が可能である. 式(8) (16)はカルマンフィルターの基礎式である. 式 (7) のような 1 階線形の微分方程式の解は, 時間ステップ $m$ に対する漸化式(システム方程式) として式 (8) のように与えられる. また, ここでの観測方程式, 式 (9) では蛍光光度計で連続的に計測されているクロ ロフィルa に基づく. 今回の事例では, 流出水路のSt.4で蛍光光度計によりクロロフィルa の実測值が毎 正時得られており, その日平均值を最下流のボックス(ボックス 3) のオンライン情報として入力すること となる. 式(8)に基づく, 状態変量伝達方程式(式(12)) からいわゆるオフライン值 $C_{m}(-)$ が算出できる. 
これと観測值 $z_{m}$ に基づき, 状態変量 更新方程式(式(15)) で修正值となる オンライン值 $C_{m}(+)$ を算出し, それ に基づき 1 日先毎の予測を 7 日先ま で進めていく.オンライン更新の際 の修正係数であるカルマンゲイン (式 (14)) を推定するために必要な状態変 量の誤差分散・共分散は式(13), (16) から与えられる。

\section{2 予測の境界条件}

ここで, 水質予測の際に与える境 界条件を整理する. 始めに, 流量と湿 度, 風速の実測值を予測開始日に与 え，この条件が予測期間中は一定に 続くものとした. また, 大気水面間の 熱フラックスの推定や生態系モデル の境界条件として気温, 日射量が必要 である.これについては, 気象庁より 毎日発表されている週間天気予報を 利用した. 図一6に石狩地方に出され た予報日より 3 日後の気温の予報値 と, モデル水域の近傍で観測された実 測值の比較図を示す. この相関関係か ら予報值を当該地域の局所的な気温 に換算して与えている. 日射量は, 八 田ら ${ }^{10)}$ の分類にしたがい天気パター ンと日照率の関係から推定し, 表-3 のように予報された天気パターンか ら日照率を求め，日射量に換算して いる.このほか, 流入水温は気温との 相関関係から, 流入負荷量は負荷量一 流量 $(L-Q)$ 関係式から与えている.

\section{6. 水質の予測結果}

計算例として，クロロフィルaの 変化の傾向など条件が違う 1994 年 と 1995 年の例で検証した. case 1 は 対象期間が 1994 年の 7 9 月の 3 力月 間で, 気温が例年に比べ高いなどの 条件で, 植物プランクトンの増殖が 盛んだったケースである. case 2 は対 象期間が 1995 年の $7 \sim 9$ 月の 3 力月間 で,この期間は 1994 年の同期問と比 ベても, 気温が低く, 日照時間も短い などの条件で植物プランクトンの増 殖はあまりみられなかったケースで ある.

図-7, 図-8にcase 1, case2 の予測 結果を示す. その結果, クロロフィル aの変動が激しい場合は, 多少ばらつ
Forecasted temp. $\left({ }^{\circ} \mathrm{C}\right)$

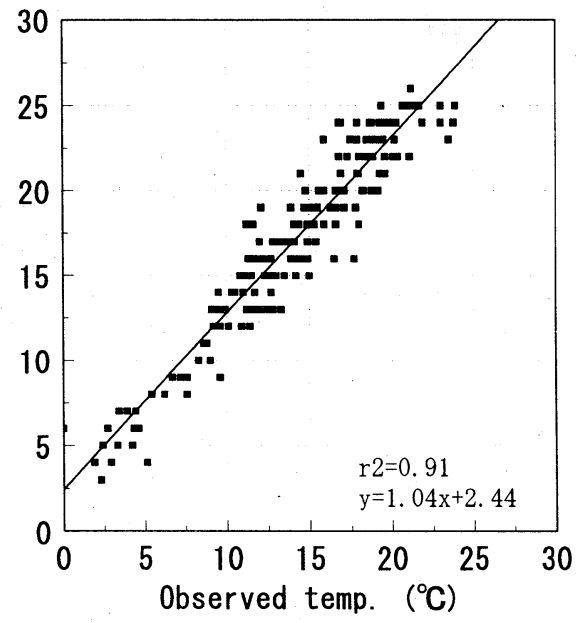

図-6 週間天気予報の気温予報值 (3 日後) とネシコシの気温実測値の比較

表-3 天気パターン別の日照率の平均値 $\left(1989 \sim 1991\right.$ 年, 札幌, 八田ら $\left.{ }^{10)}\right)$

\begin{tabular}{|c|c|c|c|c|c|c|c|c|}
\hline 分解悉 & 天気概況 & 日照率 & 分辉唩号 & 天気概況 & 日照率 & 分視䆏 & 天気概況 & 日照率 \\
\hline 1 & 晴 & 0.771 & 6 & 是 & 0.264 & 11 & 雨 & 0.059 \\
\hline 2 & 晴一時貟 & 0.521 & 7 & 是一時晴 & 0.349 & 12 & 雨一時晴 & 0.269 \\
\hline 3 & 晴後㟟 & 0.507 & 8 & 是後晴 & 0.366 & 13 & 雨後晴 & 0.346 \\
\hline 4 & 晴一時雨 & 0.498 & 9 & 㟟一時雨 & 0.163 & 14 & 雨一時暴 & 0.145 \\
\hline 5 & 晴後雨 & 0.468 & 10 & 是後雨 & 0.106 & 15 & 雨後量 & 0.103 \\
\hline
\end{tabular}

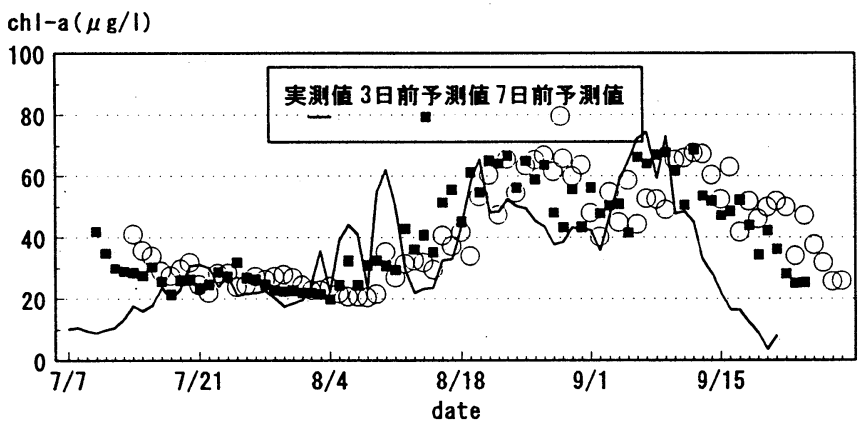

図-7 chl-a の予測結果 (case1，1994 年)

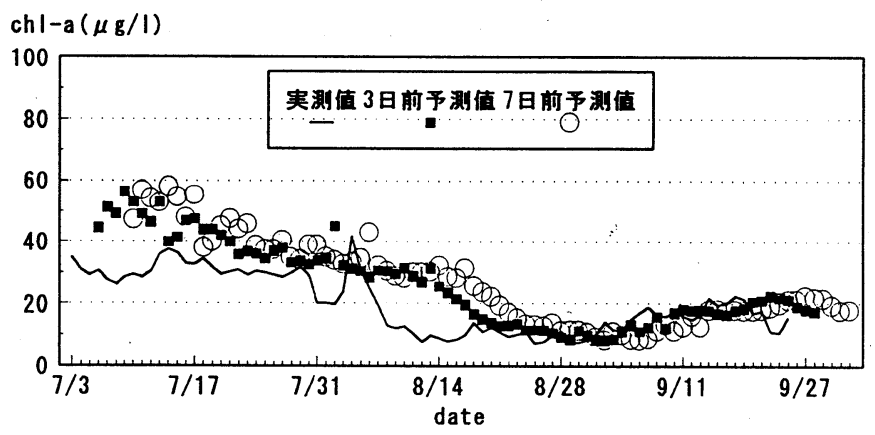

図-8 chl-aの予測結果 (case2, 1995 年) 
きはあるもののその変動傾向を十分予測できている.ただし, 流入負荷が卓越して水質変化が見られる場 合などは, 流入量, 負荷量の予測をおこなっていない分精度が落ちている. また, クロロフィルaがそれほ ど変化しない場合は, 今回予測をおこなった最大 7 日前の予測であっても精度の高い予測結果が得られ た. これは内部生産など水質モデルのパラメータを現地調査や室内試験から綿密に決定し，十分にモデル の信頼性を高めておいたことによるものと考えられる.

今回の検証結果からカルマンフィルター理論を用いたクロロフィルa 0 数日後予測手法は, 観測された 連続デー夕に基づき，その変動傾向を的確に予測できることが確認された. ただし，境界条件である流入 量や負荷量などの不確定要因を, 水文学的見地や対象地域の土地利用状態, 土質条件などの負荷発生要因 の見地から改善していくことが今後の課題と考える.

\section{7. あとがき}

本研究で得られた知見を以下に箇条書きにする.

1) 蛍光光度計により十分な精度でクロロフィルaの連続観測値が得られる.

2) 水質再現モデルにカルマンフィルターを適用し, 数日後までの水質(クロロフィルa) 予測が可能 となった。

3) 水質予測の境界条件である気温, 日射量の推定に週間天気予報の適用を図った.

本研究の意義としては, 蛍光光度計を用いたクロロフィル $\mathrm{a}$ の連続観測手法や週間天気予報, カルマン フィルターを用いたクロロフィルaの短期間予測手法が富栄養化水域の水質現象の監視および予測に有 効であることが確認できたことにある.

今後, 水質成分の負荷量などの不確定要因の精度向上を目指すとともに, 実際に現地の蛍光光度計と電 話回線などを利用し，オンラインでパソコンに観測值を入力するなどして，リアルタイムでの水質予測に 生かしていきたい. これによってアオコの発生や水質上の障害が予知できれば現場での体制づくりにも 寄与できると考える. そのためには綿密な事前調査により, 水収支, 熱収支, 現地条件にあった水質変化 メカニズムの解明が不可欠であると言える.

\section{参考文献}

1) 佐藤徳人, 西村豊, 益塚芳雄: 蛍光光度法による藻類監視について, 土木学会北海道支部年次学術発表 会論文集, pp.664 669, 第50 号, 1994

2) 佐藤德人, 西村豊, 益塚芳雄: 蛍光光度計による河川藻類の現地調査について, 開発土木研究所月 報,pp.37 50, No.497, 1994

3) 佐藤徳人, 大島省吾: 蛍光光度計による藻類の連続監視について, 土木学会年次学術講演会概要集, pp.1310 1311, 第 2 部 $(B), 1995$

4) 森北佳昭, 天野邦彦: 貯水池水質の予測・評価モデルに関する研究, 土木研究所報告, pp.1 109, 第 182 号- 1,1991

5) 星清: 洪水予測システムの基礎的検討 (2), 開発土木研究所月報, pp.48 68, No.386, 1985

6) 大島省吾, 中津川誠: 停滞性水域における富栄養化の調査方法之の 1 , 開発土木研究所月報,pp. $32 \sim 37$, No.505, 1995

7）大島省吾, 中津川誠: 停滞性水域における富栄養化の調査方法その 2 , 開発土木研究所月報,pp.30 38, No.506, 1995

8) 大島省吾, 中津川誠, 佐藤徳人, 山崎真一, 船木淳悟, 平野令緒, 坂井一浩: 停滞性水路における水質現 象の観測と解析，土木学会北海道支部年次学術発表会論文集，pp.336 339，第 51 号 (B), 1995

9) 藤田満士, 中津川誠: 停滞性水路における水温の数日後予測, 土木学会年次学術講演会概要集, pp.1340 1341, 第 2 部 (B), 1995

10) 八田茂実, 西村哲治, 嵯峨浩, 藤田睦博: 融雪流出予測における週間気象予報の利用について, 水工学 論文集, pp.141 146, 第 37 巻, 1993 